\title{
Officia and casuistry : some episodes
}

\section{Terence Irwin}

\section{(2) OpenEdition}

\section{Journals}

Electronic version

URL: https://journals.openedition.org/philosant/766

DOI: 10.4000/philosant.766

ISSN: 2648-2789

\section{Publisher}

Éditions Vrin

\section{Printed version}

Date of publication: 1 November 2014

Number of pages: 111-128

ISBN: 978-2-7574-0855-1

ISSN: 1634-4561

\section{Electronic reference}

Terence Irwin, "Officia and casuistry : some episodes", Philosophie antique [Online], 14 | 2014, Online since 01 November 2018, connection on 05 December 2022. URL: http://journals.openedition.org/ philosant/766 ; DOI: https://doi.org/10.4000/philosant.766

\section{(c) (i) $9 \odot$}

Creative Commons - Attribution-NonCommercial-NoDerivatives 4.0 International - CC BY-NC-ND 4.0 https://creativecommons.org/licenses/by-nc-nd/4.0/ 


\section{OFFICIA AND CASUISTRY: SOME EPISODES}

Terence IRWIN

University of Oxford

RÉSUMÉ. Les stoïciens ont joué un rôle essentiel dans le développement de la casuistique. Selon eux, une conduite morale réfléchie suppose une théorie morale, et ils s'efforcent d'appliquer la théorie morale à l'analyse de cas particuliers. Nous pouvons saisir l'importance de leur contribution en considérant la façon dont elle sous-tend le système de casuistique issu de la philosophie morale scolastique qui apparaît au XVI ${ }^{\mathrm{e}}$ siècle. Ma présentation des différentes étapes de l'histoire de la casuistique comporte de nombreuses lacunes, à la fois parce que j'ai négligé plusieurs sources importantes et parce que j'ai laissé de côté des aspects significatifs de celles que j'examine. Peut-être cependant, réduite comme elle l'est à l'essentiel, l'esquisse que je présente aidera-t-elle à mettre en lumière l'importance des stoïciens.

SUMMARY. The Stoics hold a central place in the development of systematic casuistry. They insist that practical moral reasoning depends on moral theory, and they try to use moral theory to inform moral reasoning about particular cases. We can grasp the significance of their contribution if we see how it underlies the more elaborate system of casuistry that emerges in the sixteenth century from Scholastic moral philosophy. My survey of these different stages in the history of casuistry will leave many gaps, both because I have omitted many relevant sources and because I have passed over many relevant aspects of the sources that I discuss. But perhaps the starkness of the outline that I offer will help to highlight the role of the Stoics. 



\section{Introduction}

The Stoics inherit a tradition of casuistry in moral reasoning. We are not well informed about all of this tradition, but we can identify some contributions to it. As far as we can tell, the Stoics hold a central place in the development of systematic casuistry. They insist that practical moral reasoning depends on moral theory, and they try to use moral theory to inform moral reasoning about particular cases. We can grasp the significance of their contribution if we see how it underlies the more elaborate system of casuistry that emerges in the sixteenth century from Scholastic moral philosophy. My survey of these different stages in the history of casuistry will leave many gaps, both because I have omitted many relevant sources and because I have passed over many relevant aspects of the sources that I discuss ${ }^{1}$. But perhaps the starkness of the outline that I offer will help to highlight the role of the Stoics.

The casuistical aspect of moral thinking allows us to explore one aspect of ancient moral philosophy. We may begin with a contrast that Julia Annas draws between ancient and modern theories:

Ancient theories assume that the moral agent internalizes and applies the moral theory to produce the correct answers to hard cases; but the answers themselves are not part of the theory. Nor are they produced by the theory in the sense that applying the theory to a simple description of a hard case will automatically generate a correct answer. Thus for ancient theorists it is true that there is not much to be said in general about hard cases. Modern theorists often see it as a demand that they be able to generate answers to hard cases in a comparatively simple way; and to this extent ancient ethics fails to meet modern demands on casuistry ${ }^{2}$.

Annas returns to these questions with a more complicated contrast between ancient and modern theories:

1. Some of the gaps are filled by the historical treatments of casuistry in Kirk 1927, and Jonsen and Toulmin 1988.

2. Annas 1993, 6-7. I have discussed this passage in Irwin 1994. 
Indeed ethical theories are not seen [sc. by the ancients] primarily as mechanisms for answering ethical questions at all... although the agent who has absorbed an ethical theory will thereby be provided with means to solve the problems that confront him, there is no expectation that ethical theory will provide a decision procedure for solving hard cases which would lack a solution without it. ... We do in fact have lists of textbook problem cases from the Stoics, together with their answers to them. And it is not hard to find passages like that in which Cicero comments on importance of rules and principles in moral philosophy, because of the need to determine one's duty in all areas of one's life. But the theory is not driven, or structured by this demand; the energy, and the basic arguments, are devoted to producing a convincing account of our final end ${ }^{3}$.

In this paper I am not trying to disagree with Annas; on the contrary, much of what I will say confirms her claim about what is primary in ancient ethical theory. Nor do I mean to suggest that ancient ethical theories are meant to provide a 'decision procedure', if that refers to an effective method that can be used, without any further moral judgment, to resolve all hard cases. My aim is to emphasize a point that Annas neither denies nor affirms. Some ancient moral theories are intended to provide principles that are necessary for the correct response to moral perplexities. They claim to succeed in this task precisely because they are not intended primarily as mechanisms for resolving practical problems; for the right way of resolving practical problems depends on the broader viewpoint of a theory that is not devised simply to resolve these problems.

This claim about moral theory and practical problems is simply a paraphrase of Seneca. But before we come to Seneca, it will be useful to mention some parts of the tradition that precedes him.

\section{Plato and Simonides}

Plato's Republic is intended to answer a practical question that can arise in both easy and hard cases: when should I keep promises? At any rate, he introduces this question near the beginning of Book I. Plato expresses two common and reasonable assumptions about the content of moral virtues: (1) They commit us to general principles requiring specific actions in specific circumstances. (2) Any informative and applicable generalizations that we can find seem to have exceptions. Plato expresses these two thoughts in one of Socrates' early questions about justice. Socrates asks whether justice is speaking the truth and giving back what one has borrowed, and he suggests that it is not, because it is sometimes not just to give back what one 
has borrowed - if, e.g., we have borrowed a friend's sword and he wants it back to kill himself when he is not in his right mind $^{4}$.

If we concentrate on examples of this sort, we may be inclined to reject our first assumption, and so to deny that the virtues commit us to general principles; for we may suppose that every principle we put forward can be refuted by counter-examples. But Socrates does not endorse this reaction. For immediately he turns to Simonides' account of justice as rendering what is due to each person ${ }^{5}$. Socrates argues that this account needs to be clarified, but he does not reject it; it is not subject to exceptions, once it is properly understood. It constitutes a basic element in the argument about justice in the Republic as a whole.

Plato does not present the question about paying debts as a case of conscience. But we easily present it in this light. Plato's answer to the question such as 'Should I return this sword that I have promised to return?' and the more general question 'Should I keep my promises?' is No. But his answer to the question 'Should I render what is due to each person?' is Yes. He believes that some ethical generalizations have exceptions, but others apply without exception. These examples may serve to illustrate the difference between a principle and a rule of justice. ${ }^{6}$ Whereas rules of justice may have exceptions, the exceptions are explicable by reference to the principles of justice, which have no exceptions. In Socrates' example about returning the sword, we do not find that we ought not to return the sword by appeal to some consideration external to justice. Socrates does not argue, for instance, that it would be just but not benevolent to return the sword. Principles of justice itself show us why the rule of returning what we have borrowed is inadequate.

\section{Aristotle on rules and exceptions: equity and friendship}

Aristotle recognizes a similar difference between generalizations that have exceptions and those that hold without exception, and he places principles of justice in the latter class. In his view, the virtue of justice requires more than rules that have exceptions. He explores the scope of justice in his discussion of 'decency' or 'equity' (epieikeia). At first sight, we seem to need equity in cases where too strict an adherence to justice seems to result in a bad outcome ${ }^{7}$. But Aristotle rejects this argument for finding exceptions to justice. He argues that equity is a correction of general rules of justice. His examples are provisions of the written law, which need to be

4. Republic, 331c1-d3.

5.331e1-332b4.

6. In speaking of principles and rules I follow Scanlon 1998, 199.

7. Aristotle, EN 1137a31-b5. 
modified in particular cases ${ }^{8}$. The correct modifications conflict with the written law, but not with the legislator; for they say what the legislator would have said if he had been present in this particular situation?

In this case Aristotle offers us less than Plato offers in Republic I; he does not state any principle corresponding to the Simonidean principle that explains why a rule of justice is inadequate. We might wonder, then, whether he believes Plato is mistaken to introduce a principle underlying the rule, and we might point to his remarks about the insufficiency of universals to show that he does not believe in any such principle. But this would be an unwarranted inference from the discussion of equity ${ }^{10}$.

In EN IX 2 and EE VII 11 Aristotle discusses questions about (inter alia) what one ought or ought not to do for one's friends, and especially how far one ought to go in doing what they want. Ross aptly entitles this section 'the casuistry of friendship'11. In the EN Aristotle recalls (1165a1214) his remarks in Books I and II that the character of discourse about ethical questions has to match the subject matter; in his view, the variety of situations, circumstances, and considerations makes it impossible to pro-

8. 'The puzzle arises because the decent is just, but is not the legally just, but a rectification of it. This is because all law is universal, but in some areas no universal rule can be correct; and so where a universal rule has to be made, but cannot be correct, the law chooses the < universal rule> that is usually < correct $>$, well aware of the error being made. And the law is no less correct on this account; for the source of the error is not the law or the legislator, but the nature of the object itself, since that is what the subject matter of actions is bound to be like. And so, whenever the law makes a universal rule, but in this particular case what happens violates the universal rule, on this point the legislator falls short, and has made an error by making an unqualified rule. Then it is correct to rectify the deficiency; this is what the legislator would have said himself if he had been present there, and what he would have prescribed, had he known, in his legislation.' (EN 1137b5-24)

9. This chapter on epieikeia is discussed by Horn 2006.

10. I have discussed this aspect of Aristotle in Irwin 2000.

11. 'Here are some other questions that raise a puzzle. Must you give way in everything to your father, and obey him in everything? Or must you trust the doctor when he is sick, and should you vote for a military expert to be general? Similarly, should you do a service for your friend rather than for an excellent person, and return a favour to a benefactor rather than do a favour for a companion, if you cannot do both? Surely it is not easy to define all these matters exactly. For they include many differences of all sorts - in importance and unimportance, and in the fine and the necessary. Still, it is clear that not everything should be rendered to the same person, and usually we should return favours rather than do favours for our companions, just as we should return a loan to a creditor rather than lend to a companion. But presumably this is not always true. If, for instance, someone has ransomed you from pirates, should you ransom him in return, no matter who he is? Or if he does not need to be ransomed, but asks for his money back, should you return it, or should you ransom your father instead? Here it seems that you should ransom your father, rather than even yourself. As we have said, then, we should, generally speaking, return what we owe. But if making a gift outweighs by being finer or more necessary, we should incline to them.' (EN 1164b25-1165a4.) 
vide completely exact statements about what one ought to do in specific cases (1164b27-30). The specific questions he discusses here are about what one ought to do for various types of friends, and in particular whether one ought without exception to follow the wishes or serve the interests of this or that type of friend - father, benefactor, virtuous companion, etc. Aristotle's answer to this question is No. But he does not reject general principles. He accepts a Simonidean principle; our decisions about what we ought to do for our parents, or friends, or benefactors, in cases where they have conflicting claims on us, should fit what is due to each of them ${ }^{12}$. If one action exceeds (byperteine(i), 1165a3) another in respect of the fine or the necessary, that is what we ought to do. He does not offer further details on what makes an action finer or more necessary.

\section{Theophrastus on weighing goods}

Though Aristotle recognizes these casuistical questions about the demands of friendship, he does not explicitly discuss a question that Aulus Gellius mentions as a standard question about friendship. Gellius gives us the question in Greek:

So too many subsequent students of philosophy, as appears in their works, have inquired very carefully and very anxiously, to use their own language,

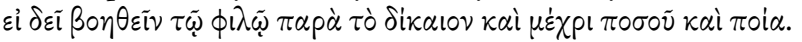

We may translate 'whether one ought to help one's friend contrary to the just, and up to how great <an injustice> and in what sorts of things'. The question recognizes that if we say we ought to help our friends contrary to justice, we raise a further question about how far we ought to go in doing this ${ }^{13}$. According to Gellius, Theophrastus raised this question in the first book of his work on friendship ${ }^{14}$.

12. 'And since different things should be rendered to parents, brothers, companions and benefactors, we should accord to each what is proper and suitable. This is what actually appears to be done; for instance, kinsfolk are the people invited to a wedding, since they share the same family, and hence share in actions that concern it; and for the same reason it is thought that kinsfolk more than anyone must come to funerals. It seems that we must supply means of support to parents more than anyone. For we suppose that we owe them this, and that it is finer to supply those who are the causes of our being than to supply ourselves in this way. And we should accord honour to our parents, just as we should to the gods, but not every sort of honour; for we should not accord the same honour to a father as to a mother, nor accord to them the honour due to a wise person or a general. We should accord a father's honour to a father, and likewise a mother's to a mother.' (EN 1165a14-27)

13. Aulus Gellius, Noctes Atticae, I 3.9.

14. On Theophrastus see Saunders 1998. According to Holford-Strevens 2003, 113, Gellius probably read this work of Theophrastus for himself, and did not simply rely on Favorinus or Plutarch. 
Theophrastus' question is relevant to Aristotle's claim that we do not owe unconditional loyalty to our friends, because the fine and the necessary are the overriding considerations. Theophrastus asks whether it might not be finer and more necessary to help one's friends even if we have to act unjustly. Gellius quotes the argument that Theophrastus presents in reply to Aristotle's claim about justice:

On this point I append Theophrastus' own words: 'It is not the case that if one thing is a more valuable sort of thing, every part whatever of this thing, compared with a complete amount of another thing, will be choiceworthy. For instance, it is not the case that if gold is more valuable than bronze, a quantity of gold compared with a quantity of bronze will seem more valuable; on the contrary, the amount and the size will carry some weight.' (Gellius NA I 26.)

He grants that considerations of justice outrank benefits to a single person. Still, he observes, it does not follow that in every particular case the just action outranks a good turn for our friend. For it may be a small matter, as far as justice is concerned, and a large increase in personal benefit. A large amount of bronze is more valuable than a small amount of gold, if the relevant amounts are large and small enough. However valuable justice may be, it does not follow that a small infraction of justice always outweighs the value of an unjust benefit.

Aristotle does not directly address Theophrastus' argument on this point. Hence Theophrastus raises a legitimate question for Aristotle. $\mathrm{He}$ implies that Aristotle's views do not provide an answer to the question about helping friends, and that in particular they do not justify a negative answer.

\section{Cicero and Theophrastus}

In De Officiis III Cicero presents a firm answer to Theophrastus' suggestion.

Duties are most disturbed, however, in friendships, in which it is against duty not to do what one can correctly do, and to do what is not fair (aequum). But for all such cases we have a short and easy precept (praeceptum). Whatever things appear advantageous - honours, wealth, pleasures, and the other things of this kind - should never be placed before friendships. But a good man will do nothing for a friend's sake either against the common weal or against his oath and promise, not even if he is a judge in a friend's case.... For if everything were to be done that friends wanted, these would have to be counted not as friendships but as conspiracies. (Cic. Off. III 43-4.) 
The summary statement 'tribuere quod non sit aequum contra officium est' gives a firm negative answer to Theophrastus. But it does not clearly address the specific question raised by Theophrastus, about a small breach of justice for a great benefit to one's friend.

Cicero's general answer to questions of the sort that Theophrastus raises is that advantage on one side cannot outweigh rightness on the other side, because nothing can be expedient on the whole if it is not right. This answer, however, leaves many casuistical questions unsolved. For in many cases the parties do not claim that their proposed course of action is so advantageous that the advantage outweighs its moral wrongness, but that it is so advantageous that the advantage makes it right. Some of Cicero's remarks suggest that we can settle whether an action is right without asking who gains or loses from it, and how much; but since gain and loss are relevant to determining rightness, he cannot plausibly claim that rightness is fixed independently of gain and loss.

This brings us back to Plato's example. We may agree with the Simonidean principle, but we cannot apply it without reference to gain and loss. For if it justifies us in sometimes refusing to return deposits, it shows us that failure to return deposits is not always wrong, and that returning them is not always right. If your friend asks you to give his sword back when he is deranged and is threatening harm to himself and others, the loss that would result from his getting his sword back would be greater than the gain, and this balance of gain and loss helps to explain why you ought not to give him back his sword. Cicero agrees with Plato's conclusions from this example (Off. III 95), but he does not make it clear that the balance of gains and losses is relevant to determining whether the action is right or wrong.

In some other cases the comparative gains and losses are relevant to the rightness of the action, but in a different way. Cicero discusses a merchant who is selling corn at high prices in a time of scarcity, but knows that several other ships are on their way with more corn. The question is not whether he should act wrongly by concealing his knowledge and profiting from the ignorance of his customers. Cicero assumes that he is a wise and good man (sapientem et bonum virum fingimus, III 50) who would do whatever he thought right, and is asking himself whether it is wrong to conceal what he knows (qui celaturus Rhodios non sit, si id turpe iudicet, sed dubitet, an turpe non sit). This question was a debated topic between Diogenes and Antipater, whom Cicero reports. But neither of them suggests that it would be wrong for the merchant to say what he knows, or that he is required to conceal what he knows; the question is simply whether it is permissible. There is no doubt that the Rhodians lose and he gains, but it is not clear how this balance of loss and gain determines rightness. Even if the Rhodians lose more than the merchant gains, it does not follow that he is 
obliged to say what he knows; the question is whether he is obliged to disadvantage himself for their benefit (III 53).

We need to vary the case to make it actually wrong to say what one knows; Cicero introduces the variation by mentioning a seller who mentions all the faults in the goods he is selling. In this case he suggests it would actually be wrong not to do what is expedient (ut id quod utile videtur non modo facere honestum sit, sed etiam non facere turpe, III 56). It is not clear why Cicero believes it would actually be wrong to be frank about the faults of what one is selling. Perhaps he thinks it is so foolish (quid vero est stultius, III 55) to show so little regard for one's legitimate interest that it would actually be wrong. This is still different from Plato's case, where we positively ought not to return the sword, because of the harm that would result to the owner and to others.

Cicero does not simply offer his intuitive reaction to each of the cases of conscience that he presents. He also tries to connect them with Stoic moral principles. He often appeals to what nature and human society require. Is it reasonable to do this? Do we learn anything by trying to explain specific judgments by these very general principles?

\section{Seneca: praecepta and decreta}

Seneca tries to answer this question in his Epistle 95, where he considers the claim that practical ethics does not require moral theory ${ }^{15}$. The opponent argues in three steps: (1) The happy life consists in correct actions. (2) Precepts lead to correct actions. (3) Therefore precepts are sufficient for correct actions ${ }^{16}$. If this argument is sound, we need only precepts if we are to act correctly. These precepts may consist of prescriptions about particular cases ('Give him back the knife you have borrowed') or of prescriptions applying to a recognizable type of action ('Give back what you have borrowed' or 'We ought to give back what we have borrowed'). Since we can find precepts of this sort without needing any philosophical doctrines, these doctrines seem to be unnecessary for correct actions.

The Stoics reject both the premisses of this argument. The second premiss is false, because, even if we have correct precepts, they do not result in a happy life unless we also have the right doctrines (decreta). The first premiss is false, because correct action is only part of the best life. The opponents who argue against the relevance of doctrines have overlooked the difference between correct actions and actions done correctly (recte facta, katorthomata). According to the Stoics, a happy life consists not only in

15. Seneca is helpfully discussed by Inwood 1999 .

16. 'Beata' inquiunt 'vita constat ex actionibus rectis; ad actiones rectas praecepta perducunt; ergo ad beatam vitam praecepta sufficiunt'. (Seneca, Ep. 95.4.) 
doing the right things, but also in doing them correctly. To do them correctly, we need philosophical doctrines:

Philosophy, therefore, being theoretical, must have its doctrines. And why? Because no one can duly perform right actions except one who has been entrusted with reason, which will enable him, in all cases, to fulfil all the measures of duties. He cannot observe these measures unless he receives precepts for every occasion, and not for the present alone. Precepts by themselves are weak and, so to speak, rootless if they are assigned to the parts. It is the doctrines that will strengthen and support us in peace and calm, which will cover at the same time the whole of life and the whole nature of things. The difference between philosophical doctrines and precepts is the same as between elements and members; the latter depend upon the former, while the former are the causes both of the latter and of all things. (95.12)

He maintains that they are the foundation and root of correct precepts. Rootless precepts without doctrines do not offer us the practical guidance that we need.

If we have only precepts that give us rules about specific types of action, we may not know how to extend them to unfamiliar cases. As Seneca says, we may grasp a precept 'in rem' but fail to grasp it 'in omne'.

Suppose that someone is doing what he should; he cannot keep it up continuously or consistently, since he will not know the reason for so acting. Some things will turn out to be correct because of luck or practice; but he will have no rule to hand by which they may be regulated and in which he may be confident that the things he has done are correct. Someone who is good by chance will not promise to be good permanently. (39)

Stoic doctrines guide our decisions because they tell us not to choose the accumulation of wealth, security, and comfort, over the demands of virtue. If we would be inclined to deviate from the requirements of virtue in cases of greater difficulty or temptation, a grasp of the proper relation of virtue to indifferents will remove this inclination.

We can use Stoic doctrines to decide unfamiliar or perplexing cases because these doctrines tell us what is morally relevant. The relevant considerations are those that help or hinder the life in accordance with nature, which provides the objective (propositum) for virtuous action.

Marcus Brutus, in the book which he has entitled On Duty gives many precepts to parents, children, and brothers; but no one carry out these precepts in the way he ought to unless he has something he can refer them to. We must present the goal of [i.e. consisting in] the highest good towards which we may strive, and to which all our acts and words may look towards 
- just as sailors must guide their course by some star. A life without an objective is erratic. And if an objective is to be presented, doctrines begin to be necessary. (45-6)

The better we understand the life according to nature, the better our grasp of what to do in different kinds of cases.

The appeal to nature is relevant, in Seneca as in Cicero, because human nature forms a system or whole, and the different precepts deal with parts. We might have a precept about keeping promises, but we ought not to keep them in all circumstances, as Plato makes clear. We decide this question by recalling that people ought not to be given the means to satisfy their irrational suicidal impulses. We take this to be relevant because we have some idea of the interests that are to be served by the specific moral precepts we might accept - whether these are in particular ('Give him the knife back now') or general ('Give back what you have promised to give back'). On a larger scale the same point applies to other precepts.

I can pass on this short rule (formulam) of human duty: all this that you see, which includes both divine and human things, is one - we are the parts of a great body. Nature produced us related to one another, since she created us from the same things and for the same things. She implanted mutual love in us, and made us suitable for society (sociabiles). She determined what is fair and just. Because of how she constituted us it is more wretched to harm than to be harmed. From her command, let our hands be ready for all who are to be helped. (51-2)

And so a fuller conception of the life in accordance with nature tells us how they fit together and when one should take precedence over another.

Even if we could always decide the right (honestum) thing to do, we could not do without Stoic doctrine, because we might sometimes be inclined not to do what we believe to be right. Our commitment to precepts will be weakened if something out of the ordinary happens - if, for instance, it is more difficult or dangerous than usual to follow a precept, even though we recognize that it still applies to us. But Stoic doctrines maintain our confidence when we face such situations (securitatem nostrum tranquillitatemque tueantur, 92.12). They do this because they tell us that happiness consists in being virtuous, so that we have no reason to deviate from what virtue requires for the sake of some other apparent benefit. We are free from anxiety, because we understand that the sources of our well-being are not endangered from circumstances beyond our control.

Moreover, even if we perform all the right actions, we do not perform them for the right reason unless we have some grasp of what is right about them. 
Furthermore, precepts will ensure that you do what must be done; but they will not ensure that you do it in the way it must be done; and if they do not ensure this, they do not lead you all the way to virtue. I grant that if someone is instructed, he will do what must be done. But that is a small matter, since the praise is not in what is done, but in the way it is done. (40)

Since morality is not only about what we do, but also about why we do it, and about the character that underlies the action, we do not simply need some means to reach the right answers and some means to ensure that we act on the right answers, we also need access to the right reasons. Two people might perform the same actions, but from different motives and different traits of character. The right trait of character depends on the right reasons, and the right reasons come from Stoic doctrine.

\section{The precepts of natural law}

If we try to apply Seneca's principles to casuisitical questions, what will be the results? Among the examples one might offer in order to answer this question, it may be worthwhile to survey the acute discussion of principles and rules in Suarez's treatment of the Decalogue ${ }^{17}$. In his view, the Decalogue is a series of divine commands that differ from other divine commands in belonging to natural law. The precepts of natural law state requirements of 'intrinsic morality'; that is to say, they prescribe actions that are right in themselves, apart from whether anyone prescribes them. God's command and prohibition presuppose this intrinsic rightness ${ }^{18}$ and wrongness in actions themselves ${ }^{19}$.

Since Suarez speaks of the 'prescriptions' or 'precepts' (praecepta) of natural law, we may suppose that he has in mind the practical rules that Seneca calls 'praecepta'. And indeed Suarez's conception of a precept is similar to Seneca's, in so far as both take a precept to be a prescription for guiding action. Suarez also agrees with Seneca's view that precepts alone are insufficient without doctrines (Seneca's decreta). But his view is more complex than Seneca's, because he believes that we do not even know the content of the relevant precepts without reference to doctrines.

Suarez considers precepts of natural law such as 'Do not kill'. In his view, we ought not to suppose that these are rules parallel to 'A deposit must be returned'. Such rules have exceptions, and so, if precepts of natural law are to be understood in the same way, they have exceptions. Suarez, however, maintains that the precepts of natural law have no exceptions. We think they have exceptions only because we fail to distinguish the

17. I have given a few more details on Suarez's views in Irwin 2008, $\$ 444-6$.

18. Suarez, De bonitate et malitia humanorum actuum, II 2.11 (= Opera, IV).

19. Suarez, De legibus, II 6.11. 
precepts themselves from the formulations that attempt to express the precepts.

The law about returning a deposit, in so far as it is natural, is not judged in the mind so simply and unqualifiedly (absolute), but with limitation and circumspection; for reason dictates that a deposit is to be returned to one who asks for it lawfully (iure) and rationally, or <that it is to be returned> unless some reason of a just defence, a reason applying either to the commonwealth or to oneself, or to an innocent person, prevents it. Commonly, however, this law tends to be expressed only in these words: 'A deposit is to be returned'. That is because the other things are implicitly understood, and cannot all be made clear in the form of law laid down in a human way ${ }^{20}$.

'Keep promises' is an incomplete formulation of the relevant precept, because it does not contain all the qualifications that would be needed in an accurate formulation. Similarly, 'Do not kill', is an inadequate formulation of the precept about homicide. The relevant precepts contain the necessary qualifications, and so they have no exceptions.

Suarez distinguishes the rules that have exceptions from the precepts of the natural law, because he takes the precepts of natural law to be correct precepts of practical reason about what is suitable to human nature. Correct precepts cannot allow exceptions; and hence 'Keep promises' cannot be an accurate formulation of a correct precept. Since the precepts of natural law are prescriptions of correct reason, we know that they cannot be (in Stoic terms) a mere series of isolated practical rules (praecepta) with exceptions, they include circumstances and conditions. Suarez supposes that we can rely on practical reason to show that unqualified rules do not capture the precepts of natural law.

The appeal to practical reason is relevant because practical reason takes account of the systematic character of the precepts of natural law. Since natural law, taken as a whole, expresses what is intrinsically right and appropriate for human nature, the different precepts do not express separate moral requirements; they express different aspects of the relevant sort of appropriateness. Reflexion on returning deposits and on other precepts of natural law shows us that we need to limit the circumstances for returning deposits. These limits introduce other precepts and virtues; we have to know whether someone is asking 'lawfully', and whether some 'just defence' requires us to withhold the deposit.

This is the point at which Suarez appeals to philosophical doctrines (Stoic decreta). His views about practical reason, human nature, and intrinsic morality tell us what a precept of natural law must say, and therefore tell 
us why 'Keep promises' and 'Do not kill' are not accurate formulations of the relevant precepts, even though we may use them to refer to the corresponding precepts. He goes beyond the claim that we cannot apply praecepta well without decreta. In his view, we cannot even find the right praecepta without relying on the philosophical doctrines underlying the theory of natural law.

\section{Casuisitcal applications: lying}

This view of the precepts of natural law affects Suarez's treatment of specific areas of moral perplexity. If we recognize that the requirements of natural law may be complex, we find them only by attention to cases that involve some complication. We may illustrate this point by a relatively simple example, taken from his discussion of lying and deception.

He accepts the authority of Augustine, who takes the commandment against false witness to prohibit all lying (asserting what one believes to be false). But this absolute prohibition leaves many questions unanswered, since it does not explicitly cover equivocation and mental reservation. These are not instances of lying; or at least not obvious instances; for if I speak ambiguously or incompletely, I still assert, or at least mean to say, what I believe, though my audience does not take me to assert what I really assert. $^{21}$

If, for instance, I say in my halting French 'Mes chevaux sont blancs', because I have confused 'chevaux' and 'cheveux', I meant to say that my hair is white, even though I might be taken to say that my horses are white. Similarly, if I am asked whether a remark was an insult, I might begin to reply 'It was a slight irritation, but not an insult', but if I am interrupted after 'slight', I will be taken to have said that it was a slight, and so to have said the opposite of what I intended. In this case I would have lied had I intended to assert that it was a slight, but I have not lied, since the audience did not hear all that I meant to say.

Though these are blameless cases of misleading speech that fails to convey what I mean to say, more difficult questions arise when I deliberately leave unexpressed part of what I mean to say. These are cases of mental reservation, in which I 'hold back' or 'reserve' part of what I mean to say, and do not utter $\mathrm{it}^{22}$. But when is this sort of reservation permissible or required?

Suppose that Jones is considering whether to offer a job to Smith, and that Jones asks me about Smith, because I knew Smith in a previous job. Jones might ask me a number of questions, and end by asking 'Do you

21. Suarez, De iuramenti praeceptis, III 9.2 (= Opera, XIV).

22. Mental reservation is explained by Davis 1946, II, 413. 
know anything else about Smith?' If I know facts about Smith that are irrelevant to Smith's qualifications, I might say 'Nothing', where I mean 'Nothing relevant to Smith's qualifications'. The extra words belong to my 'mental reservation' (i.e. what I keep in my mind and do not utter). I did not lie to Jones by not giving irrelevant information. In this context, Suarez is right to suppose that mental reservation is legitimate. It was unnecessary to utter the reserved words, and might even have given the wrong impression (as though I were inviting questions on irrelevant matters).

But now suppose that Jones wants to collect information on Smith's private life, because Jones wants to find out something that will embarrass Smith. Jones's question 'Do you know anything more about Smith?' is intended to elicit information that is not relevant to Smith's qualifications. If I know about Jones's designs, I know what the point of his question is. If I refuse to answer, or if I say that I know nothing more that is relevant to Smith's qualification, I may create the impression that I am hiding something. And so I say 'I know nothing', with the mental reservation that I know nothing on any topic that he should be asking me about. The fact that Jones wants me to violate the appropriate expectations does not make my answer into a lie, since it is an appropriate answer given the appropriate expectations.

This argument is intended to show not that elliptical utterances are always or usually permissible, but that they are sometimes permissible. Suarez's permission for equivocation and reservation is carefully restricted. He recognizes that the mere avoidance of lies does not exhaust reasonable expectations about truth-telling. The facts about social life and communication that make it wrong to lie also make it wrong to speak deceptively or evasively without lying. We should try to make our speech convey what we mean to say, and we should not deliberately mislead our audience. Objections to lying are often equally strong objections to misleading speech in which we mean to say what we believe. The use of equivocation and deliberate omission is wrong and contrary to the needs of human society, since it undermines the normal basis of communication ${ }^{23}$. Mental reservation, therefore, should be confined to cases in which the questioner has no right to a complete and unequivocal answer and some serious harm would result from such an answer.

I have not tried to defend Suarez's particular moral judgments, but to suggest how he understands the connexion between principles, rules, and particular cases. Neither the precepts of the Decalogue nor the rest of the natural law provides a series of rules without exceptions. They have to be understood in relation to each other. To understand them in relation to 
each other we have to consider their implications in different sorts of situations where the relevant moral questions arise. To find the relevant implications, Suarez relies on the connexion between morality, the needs of human nature, and the role of society in the human good. Reference to human nature and human society do not guarantee a correct answer in every case; but that is hardly an objection to them. They are abstract, but they are neither empty nor useless. They confirm Seneca's view that philosophical doctrines are useful, and indeed necessary, for finding reasonable solutions for difficult cases. On this point Suarez supports the Stoic view that moral philosophy is the right foundation for casuistry. 


\section{BIBLIOGRAPHY}

ANNAS, J. 1993: The Morality of Happiness, Oxford, 1993.

DAvis, H. 1946: Moral and Pastoral Theology, $5^{\text {th }}$ ed. 4 vols, London 1946.

Holford-STREVENS, L. A. 2003: Aulus Gellius: : an Antonine scholar and his achievement, Oxford, 2003.

HORN, C. 2006: 'Epieikeia: the competence of the perfectly just person in Aristotle', in B. Reis and S. Haffmans (eds.), The Virtuous Life in Greek Ethics, Cambridge, 2006, ch. 5, 99-126.

INWOOD, B. 1999: 'Rules and reasoning in Stoic ethics', in K. Ierodiakonou (ed.), Topics in Stoic Philosophy, Oxford, 1999, 95-127.

IRWIN, T. H. 1994: 'Happiness, virtue, and morality', Ethics, 105 (1994), 153-77.

- 2000: 'Ethics as an inexact science: Aristotle's ambitions for moral theory', in B. Hooker and M. Little (eds.), Moral Particularism, Oxford, ch. 5.

- 2008: The Development of Ethics, vol. 2, Oxford, 2008.

JONSEN, A. R., and S. E. Toulmin, 1988: The Abuse of Casuistry: a history of moral reasoning, Berkeley, 1988.

KIRK, K. E. 1927: Conscience and its Problems, London 1927.

SAUNDERS, T.J. 1998. 'Theophrastus in the tradition of Greek casuistry', in J. M. van Ophuisjen and M. van Raalte (eds.), Theophrastus: Reappraising the Sources, New Brunswick, NJ, ch. 5, 81-95.

SCANLON, T. M. 1998: What We Owe to Each Other, Cambridge, Mass., 1998.

SuArez, F.: Opera Omnia, 28 vols. (M. André \& C. Berton, eds.), Paris, 1856-1866 (repr. Brussels, 1963).

SuAREZ, F.: Tractatus de Legibus ac Deo Legislatore, 8 vols., Madrid, 1971-81. 